JURNAL BALI MEMBANGUN BALI

Volume 1 Nomor 2, Agustus 2020

e-ISSN 2722-2462 p-ISSN 2722-2454

http://ejournal.baliprov.go.id/

\title{
Analisis Media Online sebagai Sumber Informasi Wisatawan Australia dalam Mendapatkan Informasi Virus Corona di Bali
}

\author{
I Putu Hendika Permana \\ STMIK STIKOM Indonesia \\ Email: hendika@stiki-indonesia.ac.id
}

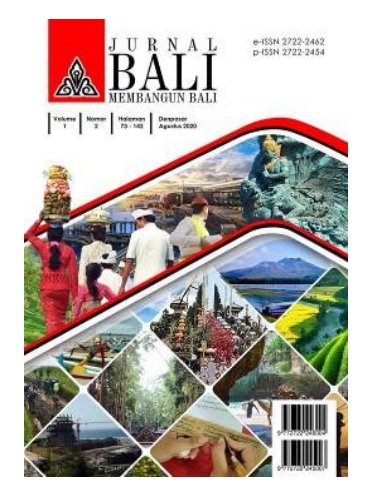

Sejarah Artikel

Diterima pada 14 Mei 2020

Direvisi pada 19 Mei 2020

Disetujui pada 29 Mei 2020

\section{PENDAHULUAN}

Virus corona yang disebut sebagai Covid-19 pada ranah ilmiah tidak hanya memiliki dampak kesehatan namun juga berdampak pada perekonomian (burhanuddin \& Abdi, 2020). Virus corona dalah virus yang menyerang pernafasan. Virus corona adalah jenis baru dari coronavirus yang menular ke manusia. Virus ini menyebabkan infeksi pernafasan ringan, seperti flu. Namun virus ini juga bisa

\begin{abstract}
Abstrak
Tujuan: Penelitan ini bertujuan untuk mencari media yang menjadi sumber informasi wisatawan Australia yang mencari informasi tentang virus corona di Bali. Australia merupakan negara pengunjung Bali tertinggi menurut disparda pemerintah provinsi Bali tahun 2019. Dalam upaya pemulihan industri pariwisata dapat memanfaatkan teknologi informasi sebagai media dalam menyebarkan informasi.

Metode penelitian: Metode penelitian menggunakan metode analisis kualitatif dengan melakukan observasi terhadap 100 artikel pada mesin pencari.

Temuan: Hasil penelitian menemukan 80 website dari 11 negara sebagai sumber informasi yang tampil pada mesin pencari. Media tersebut digunakan pemangku kepentingan untuk mengupayakan peningkatan citra positif Bali.

Implikasi: Implikasi praktis dari penelitian ini adalah untuk menyajikan daftar media online yang dapat digunakan untuk melakukan publikasi konten positif dan menarik. Publikasi diperlukan agar dapat meningkatkan keinginan masyarakat Australia untuk berkunjung ke Bali sebagai wisatawan.
\end{abstract}

Kata kunci: teknologi informasi, media online, website, pariwisata Bali, humas.

\begin{abstract}
Purpose: This research aims to look for media that are a source of information for Australian tourists who are looking for information about the corona virus in Bali. Australia is the highest visitor country in Bali, according to the provincial government of Bali in 2019. In the effort to recover the tourism industry, information technology can be utilized as a medium to disseminate information.

Research methods: The research method uses qualitative analysis methods by observing 100 articles on search engines.

Findings: The results found 80 websites from 11 countries as sources of information that appear on search engines. The media is used by stakeholders to enhance Bali's positive image.

Implications: The practical implication of this research is to present a list of online media that can be used to publish positive and interesting content. Publication is needed to make many Australians want to visit Bali as tourists.
\end{abstract}

Keywords: information technology, online media, websites, Bali tourism, public relations 
menyebabkan infeksi pernafasan berat, seperti infeksi paru-paru (pneumonia). Virus corona ini umumnya menyerang lansia tapi bisa saja menyerang bayi, Balita, orang dewasa,, termasuk ibu hamil dan ibu menyusui. Gejala umum yang menandakan orang terinveksi virus corona adalah demam, batuk kering, sesak nafas.

Sektor perekonomian merupakan sektor yang paling terlihat dampaknya di beberapa negara di dunia. Pertama-tama di Asia terlihat adanya kejatuhan bursa saham yang tidak hanya dialami oleh Indonesia, mungkin seluruh bursa saham di dunia jatuh karena sentimen virus corona. Penyebaran virus Corona yang telah meluas ke berbagai belahan dunia membawa dampak pada perekonomian Indonesia, baik dari sisi perdagangan, investasi dan pariwisata. Penerimaan pajak sektor perdagangan juga mengalami penurunan padahal perdagangan memiliki kontribusi kedua terbesar terhadap penerimaan pajak. Selain itu, penyebaran virus Corona juga mengakibatkan penurunan produksi di China, padahal China menjadi pusat produksi barang dunia. Indonesia juga sangat bergantung dengan bahan baku dari China terutama bahan baku plastik, bahan baku tekstil, part elektronik, komputer dan furniture. Virus corona ini menyebabkan kondisi ekonomi tidak stabil dan terguncang. Sektor ekonomi merupakan komponen yang sangat penting bagi kelangsungan hidup manusia. Pentingnya ekonomi bagi manusia membuat pemerintah merancang perencanaan perekonomian yang baik agar warga negaranya sejahtera.

Pandemi Covid-19 kian menebar ancaman yang mengganggu stabilitas negara-negara yang ada di dunia. Indonesia termasuk yang kena dampak besar karena banyaknya warga negara Indonesia yang menjadi korban. Hal ini dapat berakibat pada timbulnya masalah serius yang menerpa paling setiap bidang kehidupan (Purnomo, Sekti \& Alvanis, 2020). Dampak ekonomi pandemi juga diserukan Dana Moneter Internasional (IMF). Pandemi Covid-19 akan menyebabkan resesi global pada 2020 yang bisa lebih buruk dari krisis keuangan global 2008. Investor mulai bersiap menarik aliran modal, terutama modal investasi di negara berkembang. Indonesia diperkirakan akan menjadi lemah dalam perekonomian dari tahun-tahun sebelumya. Menteri Keuangan menerangkan bahwa pertumbuhan ekonomi bisa tertekan hingga level 2,5\% hingga $0 \%$ hal itu bisa terjadi ketika tidak di lakukan strategi pencegahan yang tepat. Saat ini negara telah menambahkan insentif untuk petugas kesehatan sebesar $20 \%$ dan jumlah bidang kesehatan sebesar 6,1 Triliun (Hanoatubun, 2020). 
Pariwisata merupakan salah satu komponen terbesar dalam pendapatan asli daerah kabupaten dan kota di Bali. Dampak penularan virus corona menyebabkan terjadinya penurunan kunjungan khususnya wisatawan. Perekonomian Bali saat ini merupakan kondisi terburuk sepanjang sejarah yang ada karena tingkat hunian hotelnya zero (nol). Agen perjalanan, hotel, transportasi, pemandu wisata, hingga restoran pun terkena dampak dari virus corona ini. Efek samping dari kejadian tersebut tentunya para pekerja juga terkena dampak virus corona bagi perekonomian sektor pariwisata. Pengurangangan waktu kerja sampai dengan pemutusan hubungan kerja pun marak terjadi. Sejumlah stimulus yang disiapkan pemerintah untuk membangkitkan sektor pariwisata tak mampu membendung dampak negatif corona COVID-19. Atraksi wisata banyak ditutup yang berarti tak ada pemasukan bagi mereka.

Australia merupakan negara terbesar sebagai pengunjung pulau Bali menurut data kunjungan wisatawan dari januari sampai dengan desember tahun 2019 (Disparda Bali, 2019). Australia pada saat ini sedang mengalami goncangan ekonomi. Bursa saham di Australia jatuh 7\% pada triwulan pertama tahun 2020. Kekhawatiran akan dampak penyebaran virus corona ke ekonomi, dan jatuhnya harga minyak dunia menjadi sentimen negatif kejatuhan bursa saham Australia. Badan pusat statistik Bali merilis data kunjungan wisatawan sebayak lebih dari 1,2 juta wisatawan yang sekaligus merupakan negara dengan wisatawan terbanyak yang mengunjungi Bali (Badan Pusat Statistik Provinsi Bali, 2019).

Tabel 1.10 besar wisatawan mancanegara yang datang langsung ke Bali menurut kebangsaan

[Sumber: BPS Provinsi Bali]

\begin{tabular}{ccc}
\hline Peringkat & Negara & Kunjungan \\
1 & Australia/Australia & 1.241 .128 \\
2 & RRC/China & 1.186 .057 \\
3 & Eropa Lainnya/Other Europe & 530.450 \\
4 & India/India & 374.043 \\
5 & Inggris/United Kingdom & 287.201 \\
6 & Amerika Serikat/USA & 276.859 \\
7 & Jepang/Japan & 257.959 \\
8 & Korea Selatan/South Korea & 213.356 \\
9 & Perancis/France & 206.941 \\
10 & Jerman/Germany & 196.774 \\
\hline
\end{tabular}


Untuk mengembalikan tingkat kunjungan, diperlukan analisa media yang menjadi sumber informasi wisatawan australia dalam mengembalikan kepercayaannya untuk kembali berwisata ke Bali. Hasil penelitian dapat digunakan sebagai acuan untuk pemangku kepentingan terhadap citra pariwisata di Bali. Citra positif Bali perlu dijaga untuk mempertahankan pariwisata Bali karena merupakan salah satu dari 8 faktor daya tarik bagi wisatawan mancanegara untuk berkunjung ke Bali (Suradnya, 2005)

Pembangunan citra positif yang efektif salah satunya dapat dilakukan melalui media online yaitu website (Apriananta et al., 2018). Semakin intensnya pemberitaan membuat masyarakat memantau perkembangan terkait COVID-19 melalui berbagai media seperti televisi dan media online yang salah satu nya adalah website. Kecepatan (aktualitas) informasi kejadian atau peristiwa di lapangan dapat langsung di-upload ke dalam situs web media online ini, tanpa harus menunggu hitungan menit, jam atau hari, seperti yang terjadi pada media elektronik atau media cetak. Dengan demikian mempercepat distribusi informasi ke pasar (pengakses), dengan jangkauan global lewat jaringan internet, dan dalam waktu bersamaan umumnya informasi yang dan ada tertuang dalam bentuk data dan fakta bukan cerita. Kesinambungan promosi Bali sebagai destinasi wisata yang aman dan kondusif ini penting untuk meyakinkan calon wisatawan mancanegara yang mau berlibur di Bali (Solihin \& Budiarta, 2018). Penyebaran informasi tentang Bali yang aman dan kondusif dapat dilakukan melalui media website yang sering dikunjungi oleh wisatawan australia, sehingga perlu dilakukan penelitian tentang website apa saja yang menjadi sumber informasi disaat pandemi ini yang mana pada akhirnya akan dilakukan strategi pengemBalian citra positif melalui website yang pada saat ini memberitakan COVID-19 di Bali.

\section{METODE PENELITIAN}

Penelitian ini menggunakan analisis deskriptif kualitatif, yaitu penelitian dasar yang bertujuan untuk menjelaskan fenomena dengan sedalam-dalamnya melalui pengumpulan data sebanyak-banyaknya. Penelitian ini merupakan jenis penelitian yang temuan-temuannya tidak diperoleh melalui prosedur statistik atau bentuk hitungan lainnya (Gunawan, 2016).

Teknik pengumpulan data yang digunakan adalah teknik observsi yang merupakan salah satu kegiatan ilmiah empiris yang mendasarkan fakta-fakta lapangan maupun teks, melalui pengalaman panca indra tanpa menggunakan 
manipulasi apapun (Hasanah, n.d.). Observasi dilakukan untuk mengamati, menyaksikan, memperhatikan sebagai metode pengumpulan data penelitian. Proses pengumpulan data menggunakan metode observasi nonpartisipan yang mana pengumpulan dilakukan secara independen dan data yang dikumpulkan tidak mendalam, tidak sampai pada tingkat makna.

Data sampel dalam penelitian ini adalah 100 artikel yang terdapat pada website yang populer di akses oleh wisatawan australia untuk mendapatkan informasi tentang Covid-19 di Bali. Website merupakan sebuah media yang digunakan untuk mencari informasi tentang tempat wisata (Wellem \& Dan, 2009). Artikel pada website menjadi sampel karena website merupakan media yang diminati karena Informasi disampaikan secara terus- menerus dan selalu terdapat pembaruan (updating) informasi. Penyajian yang bersifat realtime ini menyebabkan tidak adanya waktu yang diiistemewakan (prime time) karena penyediaan informasi berlangsung tanpa putus, hanya tergantung kapan pengguna mau mengaksesnya. Dengan demikian pengguna website bisa kapan saja mendapatkan informasi tanpa harus mengikuti waktu tayang.

Observasi dilakukan pada mesin pencari untuk menemukan 100 artikel yang mengandung pembahasan tentang virus corona di Bali. Mesin pencari diatur agar mengeluarkan hasil pencarian dengan bahasa inggris dan lokasi di negara australia.

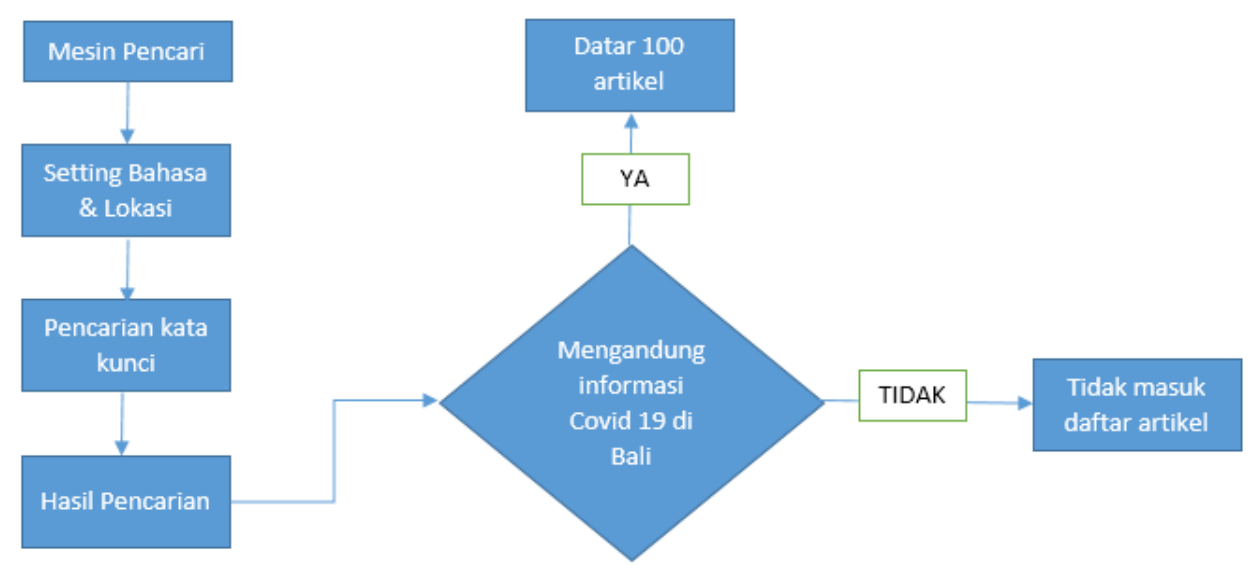

Gambar 1. Bagan pengumpulan data sampel [Sumber: dokumen rancangan bagan] 


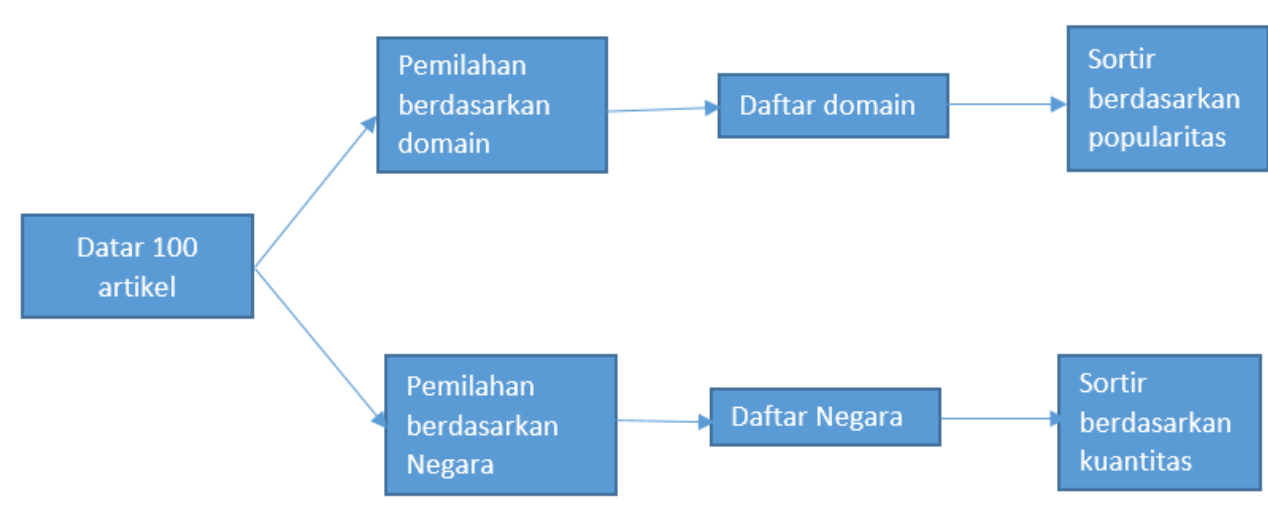

Gambar 2. Pengelompokan data sampel

[Sumber: dokumen rancangan bagan]

Analisis data dilakukan untuk melakukan pengelompokan 100 artikel menjadi terkelompok sesuai dengan domain/perusahaan nya dan terkelompok sesuai dengan negara dimana domain/perusahaan tersebut berada.

Pengelompokan berdasarkan domain/perusahaan disortir berdasarkan popularitas. Popularitas yang dimagsud adalah peringkat pada search engine. Hasil pencarian teratas merupakan artikel yang paling populer. Pengelompokan berdasarkan negara disortir berdasarkan kuantitas. Kuantitas yang dimagsud adalah jumlah negara terbanyak akan menjadi negara yang tertinggi nilainya pada hasil pengelompokan.

\section{PEMBAHASAN}

Observasi dilakukan menggunakan mesin pencari google.com yang telah diatur bahasa dan lokasi pencarian.

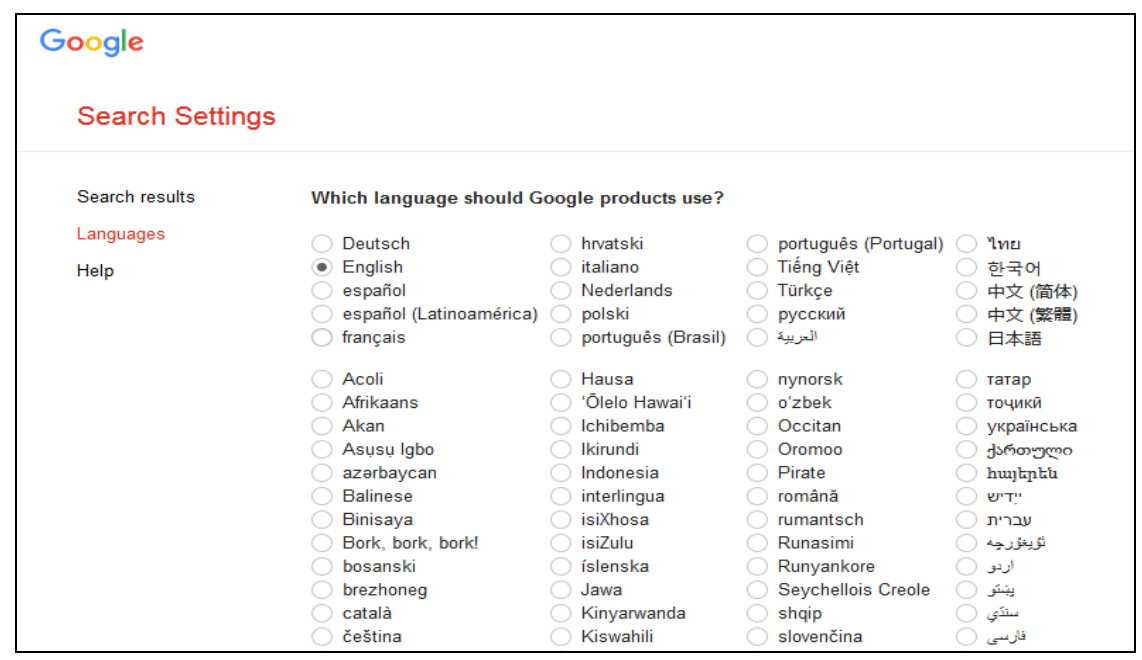

Gambar 3. Pengaturan bahasa [Sumber: search setting google.com] 


\begin{tabular}{|c|c|c|c|}
\hline \multicolumn{4}{|l|}{ Region Settings } \\
\hline Current Region & Andorra & Armenia & Bahrain \\
\hline Afghanistan & Angola & - Australia & Bangladesh \\
\hline Albania & Anguilla & Austria & Belarus \\
\hline Algeria & Antigua \& Barbuda & Azerbaijan & Belgium \\
\hline American Samoa & Argentina & Bahamas & Belize \\
\hline Benin & Germany & Mauritius & Seychelles \\
\hline Bhutan & Ghana & Mexico & Sierra Leone \\
\hline Bolivia & Gibraltar & Micronesia & Singapore \\
\hline Bosnia \& & Greece & Moldova & Slovakia \\
\hline $\begin{array}{l}\text { Herzegovina } \\
\text { Botswana }\end{array}$ & Greenland & Mongolia & Slovenia \\
\hline
\end{tabular}

Gambar 4. Pengaturan Lokasi Pencarian

[Sumber: region setting google.com]

Pengaturan bahasa dan lokasi pencarian dimagsudkan untuk menampilkan hasil pencarian yang tampil di lokasi tersebut dan dalam hal ini adalah australia. Pengaturan tersebut digunakan untuk meneliti informasi yang timbul dari manapun, namun tetap menghasilkan hasil pencarian yang sama jika melakukan pencarian langsung dari negara australia. Jumlah artikel yang dianalisa adalah 100 artikel dan hasilnya akan di klasifikasikan menjadi daftar media online yang menerbitkan informasi terkait berita virus corona.

Observasi dilakukan dalam 1 hari pada tanggal 17 April 2020. Ditemukan 136 artikel hasil pencarian, namun penelitian ini dibatasi hanya meneliti 100 artikel. Dari keseluruhan hasil pencarian ditemukan adanya beberapa artikel yang terpublikasi dari website yang sama. Sebuah website mempublikasikan lebih dari 1 artikel dan ter-indeks oleh mesin pencari google.com dan ditampilkan pada hasil pencariannya. Pengolahan data dilakukan pada keseluruhan hasil pencarian artikel untuk melakukan filtrasi artikel dengan tujuan menemukan website utama dari artikel. Ditemukan terdapat 80 website utama yang mempublikasi 100 artikel yang dihasilkan mesin pencari.

Tingkat kunjungan website yang ditemukan melalui mesin pencari akan semakin tinggi jika website berada pada halaman 1 mesin pencari atau 10 hasil pencarian tertinggi (Achmady, 2016). Hasil pencarian teratas merupakan website yang populer atau paling banyak di kunjungi. Untuk mendapatkan informasi popularitas dari 80 website yang ditemukan, diperlukan observasi terhadap 80 
website tersebut. Berikut hasil popularitas dan daftar 80 website dari hasil pengolahan data.

Tabel 2. Tabel daftar popularitas dan website 1-40

[Sumber: pengolahan data]

\begin{tabular}{|c|c|c|c|}
\hline No & Website & No & Website \\
\hline 1 & aljazeera.com & 41 & tripadvisor.com.au \\
\hline 2 & theguardian.com & 42 & gulfnews.com \\
\hline 3 & 7news.com.au & 43 & geraldtonguardian.com.au \\
\hline 4 & bali.com & 44 & jetstar.com \\
\hline 5 & balispiritfestival.com & 45 & sbs.com.au \\
\hline 6 & smartraveller.gov.au & 46 & balihotelsassociation.com \\
\hline 7 & abc.net.au & 47 & telegraph.co.uk \\
\hline 8 & businessinsider.sg & 48 & the-sun.com \\
\hline 9 & scmp.com & 49 & arabnews.com \\
\hline 10 & thehoneycombers.com & 50 & bloomberg.com \\
\hline 11 & channelnewsasia.com & 51 & watoday.com.au \\
\hline 12 & 3aw.com.au & 52 & beunsettled.co \\
\hline 13 & theaustralian.com.au & 53 & kalminer.com.au \\
\hline 14 & travel.nine.com.au & 54 & thenewdaily.com.au \\
\hline 15 & ft.com & 55 & choice.com.au \\
\hline 16 & thewest.com.au & 56 & ansa.it \\
\hline 17 & reuters.com & 57 & mirror.co.uk \\
\hline 18 & themorningbulletin.com.au & 58 & newshub.co.nz \\
\hline 19 & msn.com & 59 & en.tempo.co \\
\hline 20 & baliadvertiser.biz & 60 & whtimes.co.uk \\
\hline 21 & coconuts.co & 61 & manchestereveningnews.co.uk \\
\hline 22 & au.news.yahoo.com & 62 & virginaustralia.com \\
\hline 23 & dailymail.co.uk & 63 & perthnow.com.au \\
\hline 24 & jakartaglobe.id & 64 & gladstoneobserver.com.au \\
\hline 25 & news.com.au & 65 & indonesiaexpat.biz \\
\hline 26 & smh.com.au & 66 & underwatertribe.com \\
\hline 27 & gold1043.com.au & 67 & time.com \\
\hline 28 & thejakartapost.com & 68 & hollywoodreporter.com \\
\hline 29 & gov.uk & 69 & thebalisun.com \\
\hline 30 & nypost.com & 70 & express.co.uk \\
\hline 31 & standard.co.uk & 71 & dailyrecord.co.uk \\
\hline 32 & 9news.com.au & 72 & ladbible.com \\
\hline 33 & thesun.co.uk & 73 & health.gov.au \\
\hline 34 & aseanbriefing.com & 74 & 10daily.com.au \\
\hline 35 & dailymercury.com.au & 75 & bali-gazette.com \\
\hline 36 & balidiscovery.com & 76 & racgp.org.au \\
\hline 37 & 1cover.com.au & 77 & seminyaktimes.com \\
\hline 38 & metro.co.uk & 78 & huffingtonpost.co.uk \\
\hline 39 & cnbc.com & 79 & balionlinemarketing.com \\
\hline 40 & bbc.com & 80 & aol.co.uk \\
\hline
\end{tabular}

Tabel 2 menunjukan aljazeera.com merupakan hasil pencarian nomor satu/teratas pada hasil pencarian informasi tentang virus corona di Bali yang tampil 
pada mesin pencari. Peringka kedua diduduki oleh theguardian.com dan ketiga oleh 7news.com.au. Ketiga website tersebut tentunya akan menjadi sumber acuan utama wisatawan australia yang mencari informasi tentang perkembangan virus corona di Bali.

Obeservasi dilanjutkan pada penelitian tentang pengkatagorian terhadap 80 website yang ditemukan. Pengkatagorian digunakan untuk mengetahui asal negara dari seluruh website. Pengumpulan data menggunakan teknik kunjungan masingmasing website dan melihat alamat redaksi dari setiap website. Hasil pengolahan data menunjukan terdapat 11 katagori pada keseluruhan website.

Tabel 3. Tabel katagori website

[Sumber: pengolahan data]

\begin{tabular}{ccc}
\hline No & Katagori & Jumlah \\
\hline 1 & Australia & 28 \\
\hline 2 & Indonesia & 14 \\
3 & United Kingdom & 14 \\
4 & Internasional & 11 \\
\hline 5 & Asia & 4 \\
6 & United State & 3 \\
\hline 7 & Arab Saudi & 2 \\
8 & China & 1 \\
\hline 9 & Italia & 1 \\
10 & New Zealand & 1 \\
11 & Singapore & 1 \\
\multicolumn{2}{r}{ Total } & 80 \\
\hline
\end{tabular}

\section{KESIMPULAN}

Pemulihan perekonomian di Bali membutuhkan peranan berbagai pihak. Salah satu strategi percepatan pemulihan ekonomi di Bali adalah dengan melakukan stimulus untuk percepatan pemulihan sektor pariwisata di Bali. Pemulihan pariwisata di Bali tidak akan bisa lepas dari peran media. Salah satu media yang menjadi sumber informasi wisatawan adalah website. Pemangku kepentingan untuk pemulihan pariwisata di Bali sebaiknya melakukan strategi pemasaran melalui media yang menjadi sumber informasi penyebab anjloknya pariwisata di Bali yaitu pandemi virus corona. Penelitian ini mengumpulkan data media yang menjadi sumber informasi wisatawan australia dalam mencari informasi terkait virus corona di Bali. Tujuan dari penelitian ini untuk lebih memudakan 
pemangku kepentingan mengambil tindakan dalam melakukan publikasi dalam rangka mengangkat citra Bali di kancah Internasional.

Saran untuk penelitian selanjutnya adalah agar dapat meneliti media/website yang di akses untuk mendapatkan informasi tentang Bali oleh 5 negara wisatawan dengan pengunjung tertinggi di Bali. Adapun 5 negara tersebut adalah : China, Eropa, India, Inggirs, Jepang.

\section{DAFTAR PUSTAKA}

Achmady, S. (2016). Analisis Teknik Optimasi Website Terhadap Hasil Pencarian Google.

Apriananta, Y. J., Wijaya, L. S., \& Diponegoro, J. (2018). PENGGUNAAN WEBSITE DAN MEDIA SOSIAL Latar Belakang Menurut Ruslan Rosady manajemen mendukung yang khas dan merupakan bagian dari fungsi pemeliharaan jalur bersama antara organisasi dengan publiknya, yang meliputi hal-hal yang berhubungan dengan aktivitas. Jurnal Komunikatif, 7(2), 187-209.

Burhanuddin, chairul insan, \& Abdi, M. N. (2020). Krisis Ekonomi Global dari Dampak Penyebaran Virus Corona (Covid-19). AkMen JURNAL ILMIAH, 17(1), 90-98. https://doi.org/10.37476/AKMEN.V17I1.866

Hanoatubun, S. (2020). Dampak Covid - 19 terhadap Prekonomian Indonesia. Journal of Education, Psychology and Counseling, 2.

Purnomo, Sekti, Y., \& Alvanis, P. (2020). Tinjauan Hukum Terhadap Virus Korona , Pemecatan Pegawai dan Korupsi. LawArXiw Paper, 2(2), 2003-2004. https://doi.org/10.31228/osf.io/ysju2.Telaumbanua

Solihin, S., \& Budiarta, I. P. (2018). Upaya Stakeholders dalam Pemulihan Pariwisata Bali akibat Erupsi Gunung Agung (Sebuah Model Mitigasi Bencana Untuk Pariwisata Berkelanjutan). MEDIA BINA ILMIAH, 13(4), 1127-1132. https://doi.org/10.33758/MBI.V1314.182

Suradnya, I. M. (2005). Program Peningkatan Mutu Intensifikasi (PMI), Implementasi dan Dampaknya Terhadap Pengetahuan Petani Dan Produktivitas Padi. SOCA: Jurnal Sosial Ekonomi Pertanian.

Wellem, T., \& Dan, E. D. I. I. (2009). Semantic Web Sebagai Solusi Masalah Dalam E-Tourism Di Indonesia. 2009(Snati).

\section{Referensi dari Websites}

Badan Pusat Statistik Provinsi Bali


https://Bali.bps.go.id/statictable/2018/02/09/27/jumlah-wisatawanmancanegara-yang-datang-langsung-ke-Bali-menurut-kebangsaan-20142019.html [Diakses pada 17 April 2020]

Disparda Bali. (2019). Other Nationalities. September, 2-3. http://disparda.Baliprov.go.id/wp-content/uploads/2019/10/1.-rank-2019Sept-2019.pdf [Diakses pada 17 April 2020] 
102 | I Putu Hendika Permana 